\title{
Who Will Watch the Watchmen? \\ Czech Documentary After 1989 (a Brief Resume)
}

Images

vol. XV/no. 24

Poznań 2014

ISSN 1731-45Ox

Czech society and Czech cinematography went through a short period of instability accompanied by profound transformation after the Velvet Revolution in 1989. A political system with a single ruling party was replaced by a democratic constitution and a process of economic transformation that resulted in new laws and led to full-fledged privatization of many sectors. The Czechoslovak film industry and cinematography were not spared, with now obvious consequences for even well-established companies.

During the transformation of cinematography in 1990-1992, creative groups continued to operate under a production planning model and an approval by regime leaders. The result was two years of instability that were accompanied by one main paradox - the first independent film developed by a Czech production company (Tankový prapor, dir. Vít Olmer, 1991) was produced illegally. Still under the influence of the Beneš Decrees approved in 1945 (and led to the nationalization of the cinematographic industry), private film producers were not able to shoot movies legally. The situation changed when the first law on cinematography was approved by the parliament (which came into force on the January 1, 1993), enabling the free market to enter into film production proper.

Documentary film before 1989 was in a somewhat different situation; newsreels and documentary journals were not affected by the "invisible hand of the market" (Smithean term used by Vaclav Klaus, first Minister of finance). Formerly, they were produced mainly under the charge of the Short Film State Production Company (Krátký film). During the era of normalization in socialism, Short Film and the Czechoslovak Army Film were the only institutions with relatively liberal approval processes, which gave rise to a number of excellent works (Jan Spata, Věra Chytilová, and Václav Hapl, among others).

The years of destabilization in the early 1990 os gave rise to a new production model. Czechoslovak (and later Czech) Television commissioned the production of documentaries through newly-formed independent production companies which had a relatively great deal of creative freedom and independence (Febio, Film and Sociology, K2, Dada). A perfect example of the documentary formats developing outside the production capacity of television was the work of the film studio director Fera Fenič Febio. He produced many successful television series, established an international film festival (Febiofest), and started a new era in the production of documentaries. 
The transformations brought on by the new production model greatly affected the distribution and marketing of documentaries. The main (and almost sole) distribution channel was the public broadcaster, which handled the entire process, from story development to the production, shooting, and release of films. Cinema newsreels disappeared from cinemas as part of the concept of evening programmes composed of a newsreel, short film (often documentary), and a feature film.

Czech Television and private production companies determined the dominant aesthetic form of television-produced documentaries. The technical assumption that most influenced the formal and stylistic form of television documentaries was their compatibility with TV programming slots and schedules. This mutilation of the creative value of documentaries resulted in a series of preformatted series, most of which were produced by Febio. These were mainly the GEN and GENus Czech personality profiles, a series of close-ups on social phenomena, entitled Oko (The Eye), and Ta naše povaha Česká (Our Czech Nature).

The mass production of television documentaries shortened production (filming, editing) to a minimum, and these production constraints have been preserved in the production habits of Czech Television today.[1]

On the other hand, the mass production of Febio-like documentaries allowed for the survival of significant figures in Czech cinematography, who would have been otherwise unable to adapt to the new, complicated production conditions (Věra Chytilová, Jan Němec, Jan Špáta and others). These figures later contributed to the renaissance of the Czech documentary, and made several important pieces in television production and independently, as well.

The new upheaval of documentaries
The resurrection of documentary film in the Czech Republic was affected by several important factors, including the transformation of programming at Czech Television, personnel changes and a new policy at FAMU, the emergence of new film platforms, and international experience and co-production involvement. Czech Television enabled the emergence of exceptional series and independent films under the auspices of experienced dramaturgs at the end of the 1990 (e.g., Alena Müllerová).

Among the key personalities that influenced the emergence of a new generation of significant young talents in auteur cinema was the influential documentary filmmaker, writer and philosopher Karel Vachek. In 2000, this outcast was elected (much to the dismay of many "professionals") as head of the Department of Documentary Film at FAMU. His formal and informal influence enabled the establishment of a new generation of filmmakers who brought new conceptual ideas, provocative social issues, and a committed and clear creative vision,

[1] Standard shooting time for a documentary of up to 30 minutes is $3-5$ days, and the time for editing $2-3$ days. 
including Jan Gogola Jr., Vít Janeček, Erika Hníková, Lucie Králová, Martin Mareček, Vit Klusák, Filip Remunda and Linda Jablonská.

These authors had the opportunity to develop their own profile during their student years at FAMU, and after graduation became creative personalities in their own right. Most of their graduation films were later shown in cinemas, which was unthinkable during the 1990 s. Responsibility for personal training and initiation at FAMU was assumed (alongside Karel Vachek) by filmmakers such as Jan Němec, Miroslav Janek, and Jan Špáta, but their contribution was most visible in an intimate, self-reflexive manner of filming. The new generation of filmmakers addressed audiences at festivals and in theatres both at home and abroad; they responded to social events and problems, and were characterized by an active, engaged approach to the themes and objects they shot.

A separate realm that was able to germinate undisturbed, representing the unbounded spirit of a new generation of Czech filmmakers, was the festival of documentary films in Jihlava. It began as an initiative by Marek Hovorka, a Jihlava high school student,[2] and his teacher Petra Kubica. [3] Following the first edition in 1997, the festival began to be held regularly. Since 1999, it has grown into an international event, and today is an internationally acclaimed and respected venue, known for its profound film industry programme, training events, and relaxed informal atmosphere.

Other festivals also contributed to the development of documentary film and its availability and acceptability to audiences, especially the One World human rights documentary film festival and Academia Film Olomouc, focused on popular scientific films and educational documentaries. Both festivals feature a number of related promotional, educational, and networking activities, and have come to form the backbone of Czech documentary film.

An important part of the development of documentary filmmaking in the Czech Republic is the international attention it receives and its integration into European structures and co-financing schemes. The institution primarily responsible for starting the process of integrating Czech documentary film into a European Framework is the Institute of Documentary Film (IDF), founded in alliance with the Jihlava IDFF. The IDF gave rise to the East European Forum co-production programme, the East Silver market for Central and Eastern European documentary films, and the Ex Oriente Film international workshop for documentary filmmakers and producers.

Since 2000, we can witness a gradual change that implies a redefining of documentary cinema in the Czech Republic, including the establishment of a significant place for documentaries in the public consciousness and a gradual rehabilitation of their wider importance among general audiences.

[2] Marek Hovorka is still the executive director of the festival.
[3] Programme director of the festival, and since 2012 one of the creative producers at Czech Television. 
The auteur

documentary

tradition
A "turning point" in Czech Television: creative producer groups
A key moment for the recognition of a new generation of filmmakers in the twenty-first century was the case of the graduate film Dust Games made by Martin Mareček in 2001. This film focuses on a meeting between the IMF and World Bank representatives in Prague in 2000 and became an unexpected success among audiences, the media and critics. It won the main prize at the Jihlava film festival, and was later shown in cinemas. The film reflected new approaches in documentary filmmaking style, the so-called situational documentary. The director and his crew play an interactive game within the "rules of the game", developing a range of contexts and new means of reflection in the global information age, and harnessing the refreshing power of activist images.

Alongside this appreciation of Dust Games, the Jihlava film festival began to focus and redefine itself in terms of auteur documentary, which helped in initiate a decline in the talking heads policy typical of television aesthetics of the 1990s. Creative documentary film was now clearly recognizable, and authorship[4] won a crucial role in the creation of authentic film testimonies and in the documentary film processing routine (especially for public television).

The new directing talent arising from FAMU during 1998-2003 was also linked with theoretical thinking about the nature of documentary filmmaking. This helped to define the concept of creative documentary filmmaking and avoid complications in the concept of reality and authenticity in documentaries. Prominent among the theorists of this generation were Vít Janeček and Jan Gogola Jr.. Gogola’s text[5] (and a thesis) Documentary Film Documental became a focal point for the genre, a formal and thematic document defining a new concept for documentary filmmaking in the country.

Gogola developed specific genre characteristics for documentaries, and presented his own principles for a formal typology for documentaries (information, situation, staging, stylised) and promoted the analysis of concrete examples of these concepts. At the same time, a new canon of documentary films about recent times appeared which were widely discussed in theoretical and academic circles. Developments in the design and marketing of documentaries in 2001-2006 included more intense viewer reflection, which helped establish a greater social appreciation for documentaries.

After a period of strong economic boom, an inevitable phase of sobering and balancing arose. Following the significant success of the film Dust Games (Martin Mareček), Czech Dream (Vít Klusák, Filip Remunda), The Battle of Life (Vít Janeček, Roman Vávra, Miroslav Janek) or Women Exchange (Erika Hníková), authors tried to find new topics, establish themselves in the creative and production process, and develop their professional careers. Some (Vít Janeček, Jan Gogola Jr.,
[4] In undirect connection with Politique des auteurs of François Truffaut Cahiers du cinéma critics and Auteur Theory by Andrew Sarris.
[5] DO anthology 2/2004, pp. 197-204, published by IDFF Jihlava. 
Vít Klusák) began to teach documentary film at FAMU, and most filmmakers started working more or less intensively for Czech Television.

Although the documentary films after 2007 does not offer such significant achievements in terms of quality, insightfulness topics, and compact statements, the previous boom stimulated new sensitivity to documentaries in both audiences and critics. In 2011, 45 cinema-released films were produced, among which were 18 documentary films.

The upheaval in documentary cinema, however, has also led to a significant reduction in the quality of the films. Many of them suffer from their television set design and production background; some are released in theatres more to demonstrate the support they receive from the State Fund for Cinematography than for their cinematic qualities.

A new dimension in creative work for public television was initiated by the decision of the newly named director of Czech Television Petr Dvorak[6] to establish a new group of so-called creative producers. Although the concept itself had been planned for a long time, its introduction to Czech Television brought a new approach to creative work in terms of the competencies of the directors and producers collaborating on the development of TV programs and formats.

For documentary filmmaking, this change meant a supply of new energy and hope in the production of television documentary formats. Creative producers committed to social affairs and executive producers included Jihlava IDFF program director and FAMU teacher Petr Kubica and former HBO executive producer Martina Šantavá. In addition to them, several other creative producers were committed to documentary production. [7] These creative producers were appointed in 2012 and given space to implement a number of topics, themes and formats that had not yet received sufficient broadcasting primetime or had been treated inadequately or conventionally.

A separate chapter in the chronicles of Czech documentary cinema in the new millennium is the auteur cooperation between two filmmakers, Vít Klusák (1980) and Filip Remunda (1973). They graduated in documentary filmmaking at FAMU, and both arestill actively collaborate as they work on individual projects. Although they are both known as the directors of the revolutionary and provocative social media experiment Czech Dream, both had already recorded some remarkable images before this breakthrough film.

Vít Klusák (1980) is a Czech director, producer and cinematographer. He studied photography at Hellichova High School in Prague; since his teenage years he has been an activist and has been engaged in many artistic and public happenings. He later studied at the Department of Documentary film at FAMU, where he attracted attention with his student films Začátek světa (Beginning of the World), Digestive, and Ocet (Vinegar). He studied in the studio of Karel Vachek and Helena

[6] He previously worked as a director for the private Nova TV.
[7] Such as Lenka Polaková, Kamila Zlatušková, and Alena Müllerová.
Klusák \& Remunda: a case study 
Třeštíková, and for his graduation project made the feature documentary reality show Czech Dream (Český sen, co-directed with Filip Remunda).

During the preparation of Czech Dream, Klusák and Remunda co-founded the Hypermarket Film production company, which is one of the prominent companies today. After Czech Dream, he continued to work as a cinematographer and shot several short films and music videos. In 2010, he continued with Remunda with Czech Peace, a documentary investigation about the case of a U.S. radar base that was supposed to be built in the Czech Republic. He also continued with his own projects, such as V̌se pro dobro světa a Nošovic (All the Good For the World and Nosovice) about the political backdrop behind the Hyundai assembly line in the northeastern village of Nosovice.

Since 2010, he has also worked as a professor at FAMU, and with his students released Film jako Brno (Film as Brno). After making several documentaries for Czech Television, Hypermarket Film Produced a series in 2012 called Czech Journal, which focused attention on controversial affairs in Czech society.

Filip Remunda (1973) is a Czech director and producer. In 2005, he graduated from FAMU's Department of Documentary Film in the studio of Karel Vachek. During his studies, he attended the Sam Spiegel Film and Television School in Jerusalem. He has lectured at the Flaherty Documentary Seminar in the U.S.

Remunda is a co-founder of the Institute of Documentary Film. With Vít Klusák and Tereza Horská, he runs the independent production company Hypermarket Film (founded before the production of Czech Dream). For his short film Obec B. (Village B, 2002), he received an awarded at Karlovy Vary IFF. Following his cooperation with Vit Klusák, he shot several independent films, including Pulec, králík a duch svatý (Tadpole, Rabbit and the Holy Ghost, 2007) and Epochální výlet pana Trísky do Ruska (2011).

Their joint work associated with their graduation film Czech Dream captures their essential creative credo - to find socially poignant and problematic issues and open painful wounds in society related to the notion of ambiguity. Czech Dream opened the way for an invitation from American director Michael Moore, and Klusák and Remunda are frequent guests at the Festival in Traverse City.

In 2010, they completed another picture together, once again using the phrase "Czech". In a film released in cinemas under the title Czech Peace, they created a situational documentary dealing with disputes over the building of a U.S. missile radar station in the Czech locality of Brdy. The theme develops not only issues related to Czech history, Americaphobia and nationhood, but also shows the general context of the political situation in the country, and the relationship of Czechs to international topics and issues.

The creative cooperation between Remunda and Klusák led in 2012 to another ambitious project, titled Czech Journal. The film's unique concept, combining reportage journalism and a sociological probe, was 
established under the supervision of the creative producer Peter Kubica and the film production company Hypermarket Film. Czech Journal has a quite unusual format for public television. It was made over a period of six months in 2012, and five chapters were aired during the spring of 2013, with all the parts fitting within the classical reportage length, at 52 minutes.

The establishment of Czech Journal was symptomatic of the position of the newly set up production structure of the creative producers in Czech Television and their decision-making powers. Its creation was accompanied by a series of problems and complications with approval because the series addressed a number of sensitive issues and topics. After a successful defence of the project, it was approved for implementation. The series was except Remunda and Klusák directorial intervention co-directed by Martin Dušek (Poustevna, das ist paradies, Coal in the Soul) and Lukáš Kokeš (59/64/184, The Fortress, Gottland), each of whom directed one of the parts. Czech journal is devoted to topics that stirred society in 2012, while revealing deeper principles and allegations of Czech nature and character. These included:

Presidential Election Affinities - behind the scenes of the first-ever direct presidential election

Life and Death in Tanvald - consequences of the murder of a young Roma in ethnically disturbed northern Bohemia

Freedom for Smetana - the case of politically punished bus driver in Olomouc who painted portraits disgracing of politicians

Adulterated Republic - methanol poisoning and big business in the Czech Republic

Anger - a controversial project comemorating the annihilation of village Lidice by the Nazis

Vít Klusák and Filip Remunda were creators and authors of the ideological concept behind the series, so the concentration of provocative and sensitive topics was expected and understandable. One of the parts, Freedom for Smetana, was later expanded to a feature-length version shown in theatres under the title Good driver Smetana. [8] The entire series was shown on Czech Television only once, and a sequel was postponed for ideological reasons. It is therefore likely that this was a unique opportunity to combine reportage and investigative journalism with provocative hint which will not appear on public television again.

With Czech Journal it is possible to illustrate the method used in situational documentary, which has became a distinctive creative pattern in Czech documentaries of the last fifteen years. All episodes are based on a specific, significant situation (presidential elections, the murder of a Roma in Tanvald, the convicted driver Smetana, prohibition and raids against bootleggers, the controversial premiere radio play "Ringing" about the story of Lidice), which is developed through the creative intervention of the authors.

[8] The link to The Good Soldier Swejk is obvious.

Czech Journal: the heart of darkness of Czech society 
Politics as a simulacrum and a metaphor for society
An active part in the documentaries is played by the filmmakers, who try to find and uncover the stereotypes that influence the mentality and tectonics of anger in Czech society (Tanvald, Anger), reveal the state and political interests jeopardizing freedom and people's lives (Smetana, Adulterated Republic). With their limited journalistic-investigative action, both authors of Czech Journal are fulfilling an assumption by public television, which stands on the sidelines and caters to average citizens, striving for an impartial, critical approach to the displayed events, people, and issues.

Deserving of special attention is the segment Presidential Election Affinities, which is devoted to the direct presidential election. It was the ultimate political event in Czech society in 2013, and marked the beginning of the shooting schedule of Czech Journal, which monitored the progress of the campaign. In addition, a second film was being shot in parallel: Looking for President by Tomáš Kudrna, a full-length documentary intended from the beginning for cinema audiences, produced by the Negativ production company.

If we look for fundamental differences between both films, we can see them in their purpose, function and the format in which they were created. The ambitious project of Tomáš Kudrna was created from the beginning for cinema audiences, [9] while Presidential Election Affinities (note: the name refers to the J. W. Goethe novel, but mainly a reference to the 1968 movie Elective Affinities by Karel Vachek about the politicians of the Prague Spring) originated in the Czech Journal within a limited television format.

Tomáš Kudrna tried to create an unbiased, neutral observational documentary about the election campaign of ten candidates for the President of Czech Republic. It progresses linearly and chronologically, and focuses on the highlights of the campaign and the individual specifics and interactions of the candidates. Klusák and Remunda followed a very subjective, engaged approach - the sought backstage situations, pointing out paradoxical moments that reveal the fictionalized aspects of the campaign and the lack of credibility or falsity of some of the candidates in particular. The aim was to highlight the absurdity of an excess of democracy that prevailed in the Czech Republic, and indulged victory not to the representativeness of the function (which would suit more to other candidates), but to the populism and sentimental popularity embodied in former Prime Minister Miloš Zeman.

A President with a penchant for alcohol, cigarettes and witticisms, although he became a central figure of both documents, was depicted in Czech Journal more according to his real nature, based on political arrogance and an alliance with the mysterious and shadowy lobbyist Miroslav Slouf, who played a considerable role in Miloš Zeman's tri-
[9] Negativ is one of the most successful production companies in the Czech Republic, having produced films such as Whisper (David Ondříček), Helena
Třeštíkovás movies Marcela, René, Katka, and Private Universe, and Alois Nebel (Tomás Lunák). 
umph. Vít Klusák does not hesitate to use his camera to chase Slouf after Zeman's winning the second round of the elections and ask him what he is doing there, and if he has committed an act of corruption.10

The figure of Miloš Zeman has accompanied Czech politics for nearly fifteen years, and in addition to former President Vaclav Klaus, he is evidence of political resilience and perseverance despite the views of the public. A political simulacrum (President of the common people) devoid of historical memory struts before the eyes of the audience with unprecedented power. "Sir, get out, you are detaining me, others are coming," Zeman scolds Filip Remunda during the campaign, who is using his camera to try to ask hard questions.

"Election Affinity", mentioned in the title of this chapter, describes a secret code, the coalition between the powerful and the powerless from politics and world of show business. A simple policy prescription consisting of a few catchy phrases, damaging information on the opponent, and showing oneself with showbiz and business celebrities. Thus, the team of the former chairman of the Social Democratic Party drafts the famous film director Filip Renč, a politically promiscuous and artistically routine craftsman. A comic moment occurs when a foreign reporter asks Renc why Zeman would be a better president than his opponent Karel Schwarzenberg in the second round:[11]

Why do you support Mr. Zeman. Why do you think he would be better president than Mr. Schwarzenberg?

I support Mr. Zeman because he is very good political and good (zkušenost) examination. And he is typically Czech. He is highly intelligent; he is clever, clever boy.

Despite some dramaturgically unfinished or bleak motifs, the television film Presidential Election Affinities is a far more beneficial testament to time and presidential elections than Kudrna's feature Looking for President. Kudrna glides over the surface in the form of a chronological chronicle of the election campaign and harmonically monitors the individual candidates and escalating tensions. Klusák and Remunda monitor the internal meanderings, the indirect, buried contexts that testify to the arrogance of power and simulacra of Czech post-revolutionary politics.

Both films then form a counterpart to the time-lapse monument Citizen Havel, started by Pavel Koutecký and finished by Miroslav Janek, which shows the backstage of the presidency of Vaclav Havel, full of commitment, doubts and uncertainties, but still based on political idealism and a clear humanistic vision.

What we can consider as part of Klusák and Remunda's method is their unrelenting approach to discovering crucial and provocative topics and asking questions everybody is thinking of and no one asks.

\section{Provocation and censorship}

[10] Miroslav Slouf is a dark man of Zeman's political career and during the campaign Zeman repeatedly disavowed from him.
[11] Schwarzenberg is an aristocratic, former Havel's president advisor and during the shooting current minister of foreign affairs. 
Ultimately there is a bold red line crossing all their films, from Czech Dream to Czech Journal, a rousing of common sense and national sensitivity, a committment to the legacies of who we are and who we wish to be as Czech citizens.

They discover a national and private dark side of the social consciousness, recovering a critical approach, and engaging themselves in topics that should be part of our discussions about our identity. The shorrt-term reactions are always the same: strong audience expectations and a denial by the common Czech mentality. This is also the reason for the political obstructions caused by Czech Journal in the television of public affairs, Czech Televison.

Problems with censorship and political influence in the control mechanisms of the public broadcaster remind us about the so-called "crisis in Czech television" observed in Radim Spacek's Sleepless Nights (2001). The unresolved issue of independent documentary filmmaking and corporate political interests appears to remain a crucial question for a still post-socialist society.

\section{Films:}

Starověrci (Old Believers, Jana Ševčíková, 2001)

Bezesné noci (Sleepless nights, Radim Špaček, 2001)

Hry prachu (Dust Games, Martin Mareček, 2002)

Bitva o život (The Battle of Life, Vit Janeček, Roman Vávra, Miroslav Janek)

Český sen (Czech Dream, Vít Klusák, Filip Remunda, 2004)

Ženy pro měny (Beauty Exchange, Erika Hníková, 2004)

Přes hranice (Accross the Border, Pawel Lozinski, Jan Gogola Jr., Peter

Kerekes, Róbert Lakatos, Biljana Cakić-Veselič, 2004)

Zdroj (Source, Martin Mareček, 2005)

Kupředu levá, kupředu pravá (Forward Left, Forward Right, Linda Jablonská, 2006)

Ztracená dovolená (Lost Holiday, Lucie Králová, 2007)

Poustevna, das ist Paradies (Town Called Hermitage, Martin Dušek, Ondřej Provazník, 2007)

Občan Havel (Citizen Havel, Pavel Koutecky, Miroslav Janek, 2008)

Jak se vaři dějiny (Cooking History, Peter Kerekes, 2009)

Auto ${ }^{\star}$ mat (Martin Mareček, 2010)

Ženy SHR (Coal in the Soul, Martin Dušek, Ondřej Provazník, 2010)

V̌̌e pro dobro světa a Nošovic (All for the Good of the World and Nosovice,

Vít Klusák, 2011)

Pevnost (The Fortress, Lukáš Kokeš, Klára Tasovská, 2012)

Show! (Bohdan Bláhovec, 2013)

Dál nic (Beyond anything, Ivo Bystřičan, 2013)

Dobrý řidič Smetana (Good Driver Smetana, Vít Klusák, Filip Remunda, 2013)

Looking for President (Tomáš Kudrna, 2013)

Text of Jan Gogola: Documentary film documental: <http://www.dokweb. net/cs/dokumentarni-sit/clanky/dokumentarni-cesky-film-dokumentalni-78/?off $=1560>$ 